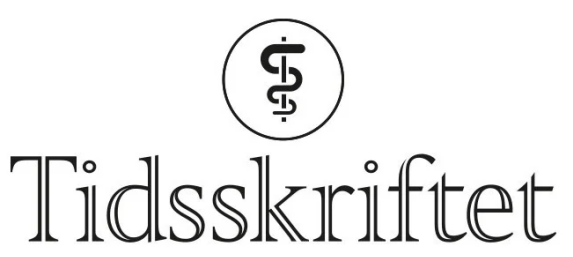

DEN NORSKE LEGEFORENING

\title{
Tre bølger med covid-19 på et norsk lokalsykehus
}

ORIGINALARTIKKEL

\section{MARIUS MYRSTAD}

marius.myrstad@vestreviken.no

Seksjon for geriatri, slag og rehabilitering

Medisinsk avdeling

Vestre Viken, Bærum sykehus

og

Forskningsavdelingen

Vestre Viken, Bærum sykehus

Han har vært hovedansvarlig for idé, utforming og design av studien, datainnsamling, analyse av data, tolking av data, litteratursøk og utarbeiding av manus.

Marius Myrstad er ph.d., spesialist i indremedisin og geriatri og overlege.

Forfatteren har fylt ut ICMJE-skjemaet og oppgir ingen interessekonflikter.

\section{PETER SELMER RøNNINGEN}

Forskningsavdelingen

Vestre Viken, Bærum sykehus

Han har bidratt med datainnsamling, analyse av data, tolking av data og utarbeiding av manus.

Peter Selmer Rønningen er lege og stipendiat.

Forfatteren har fylt ut ICMJE-skjemaet og oppgir ingen interessekonflikter.

\section{ANDERS TVEITA}

Medisinsk avdeling

Vestre Viken, Bærum sykehus

og

K.G. Jebsen-senter for B-cellekreft

Avdeling for immunologi og transfusjonsmedisin

Oslo universitetssykehus

Han har bidratt med datainnsamling, tolking av data og utarbeiding av manus.

Anders Tveita er ph.d., lege i spesialisering og forsker.

Forfatteren har fylt ut ICMJE-skjemaet og oppgir ingen interessekonflikter.

\section{ELSE JOHANNE RØNNING}

Seksjon for infeksjonsmedisin

Medisinsk avdeling

Vestre Viken, Bærum sykehus

Hun har har bidratt med datainnsamling, tolking av data og utarbeiding av manus.

Else Johanne Rønning er spesialist i indremedisin og infeksjonssykdommer og seksjonsoverlege. Forfatteren har fylt ut ICMJE-skjemaet og oppgir ingen interessekonflikter. 
Intensivseksjonen

Avdeling for anestesi, intensiv og operasjon

Vestre Viken, Bærum sykehus

Han har har bidratt med datainnsamling, tolking av data og utarbeiding av manus.

Per Erik Ernø er spesialist i anestesiologi og overlege.

Forfatteren har fylt ut ICMJE-skjemaet og oppgir ingen interessekonflikter.

\section{ELIZABETH LYSTER ANDERSEN}

Forskningsavdelingen

Vestre Viken, Bærum sykehus

Hun har bidratt med datainnsamling, analyse av data, tolking av data og utarbeiding av manus.

Elizabeth Lyster Andersen er lege og stipendiat.

Forfatteren har fylt ut ICMJE-skjemaet og oppgir ingen interessekonflikter.

\section{MARTE MEYER WALLE-HANSEN}

Forskningsavdelingen

Vestre Viken, Bærum sykehus

Hun bidratt med datainnsamling, analyse av data, tolking av data og utarbeiding av manus.

Marte Meyer Walle-Hansen er lege og stipendiat.

Forfatteren har fylt ut ICMJE-skjemaet og oppgir ingen interessekonflikter.

\section{ANDREW CAMPBELL ROBERTSON}

Intensivseksjonen

Avdeling for anestesi, intensiv og operasjon

Vestre Viken, Bærum sykehus

Han har har bidratt med datainnsamling, tolking av data og utarbeiding av manus. Andrew Campbell Robertson er spesialist i anestesiologi og seksjonsoverlege. Forfatteren har fylt ut ICMJE-skjemaet og oppgir ingen interessekonflikter.

\section{MONICA THALLINGER}

Intensivseksjonen

Avdeling for anestesi, intensiv og operasjon

Vestre Viken, Bærum sykehus

Hun har bidratt med datainnsamling, tolking av data og utarbeiding av manus. Monica Thallinger er ph.d., spesialist i barnesykdommer og lege i spesialisering. Forfatteren har fylt ut ICMJE-skjemaet og oppgir ingen interessekonflikter.

\section{JAN SVENDSEN}

Seksjon for infeksjonsmedisin

Medisinsk avdeling

Vestre Viken, Bærum sykehus

Han har bidratt med datainnsamling, tolking av data og utarbeiding av manus. Jan Svendsen er spesialist i indremedisin og infeksjonssykdommer og overlege. Forfatteren har fylt ut ICMJE-skjemaet og oppgir ingen interessekonflikter.

\section{SIGURD HAAKONSEN}

Akuttmedisinsk seksjon

Medisinsk avdeling

Vestre Viken, Bærum sykehus

Han har bidratt med datainnsamling, tolking av data og utarbeiding av manus.

Sigurd Haakonsen er lege i spesialisering og konstituert overlege.

Forfatteren har fylt ut ICMJE-skjemaet og oppgir ingen interessekonflikter.

\section{ARNLJOT TVEIT}

Forskningsavdelingen

Vestre Viken, Bærum sykehus

og

Institutt for klinisk medisin

Universitetet i Oslo 
Han har bidratt med utforming og design av studien, tolking av data, litteratursøk og utarbeiding av manus.

Arnljot Tveit er avdelingsleder og professor.

Forfatteren har fylt ut ICMJE-skjemaet og oppgir ingen interessekonflikter.

\section{HÅKON IHLE-HANSEN}

Medisinsk avdeling

Vestre Viken, Bærum sykehus

og

Forskningsavdelingen

Vestre Viken, Bærum sykehus

Han har bidratt med utforming og design av studien, datainnsamling, tolking av data, litteratursøk og utarbeiding av manus.

Håkon Ihle-Hansen er ph.d., konstituert overlege og forsker.

Forfatteren har fylt ut ICMJE-skjemaet og oppgir ingen interessekonflikter.

\section{BAKGRUNN}

Formålet med artikkelen er å oppsummere sykdomsforløp og behandling for pasienter med covid-19 innlagt på Bærum sykehus siden starten av pandemien.

\section{MATERIALE OG METODE}

Vi presenterer data fra en prospektiv observasjonsstudie med mål om å systematisere kunnskap om pasienter innlagt på grunn av covid-19. Alle pasienter innlagt på Bærum sykehus til og med 28.6.2021 ble inkludert. Resultatene presenteres for tre bølger av sykehusinnleggelser: 9.3.-23.6.2020, 21.9.2020-28.2.2021 og 1.3.-28.6.2021.

\section{RESULTATER}

I alt 300 pasienter, fordelt på hhv. 77, 101 og 122 i de tre bølgene, var innlagt på grunn av covid-19. Antallet som døde under sykehusoppholdet i de tre bølgene, var hhv. 14 (18 \%), 11 (11\%) og 5 (4\%). Gjennomsnittsalderen for innlagte var 67,6 år i første bølge og 53,3 år i tredje bølge. Totalt 204 pasienter (68\%) fikk oksygenbehandling eller ventilasjonsstøtte, og 31 av disse (10\% av alle pasientene) fikk invasiv ventilasjonsstøtte. Ikke-invasiv ventilasjonsstøtte ble brukt som høyeste nivå av behandling hos hhv. 4 (8\%), 9 (13\%) og 17 ( $20 \%$ ) pasienter med respirasjonssvikt i de tre bølgene. I andre og tredje bølge fikk 125 av 152 pasienter med respirasjonssvikt ( $82 \%)$ behandling med deksametason.

\section{FORTOLKNING}

Forskjeller i pasientkarakteristika og endringer i behandling, som i bruk av deksametason og ikke-invasiv ventilasjonsstøtte, kan ha bidratt til at dødeligheten tilsynelatende sank fra første til tredje bølge. Forhold som ikke er registrert i studien, slik som vaksinasjonsstatus, kan også ha påvirket dødeligheten.

\section{HOVEDFUNN}

Gjennomsnittsalderen hos pasienter innlagt på Bærum sykehus på grunn av covid-19 var 68 år i pandemiens første bølge og 53 år i tredje bølge.

Sykehusdødeligheten i pandemiens første og tredje bølge var henholdsvis $18 \%$ og 4 \%.

I andre og tredje bølge fikk 125 av 152 pasienter med respirasjonssvikt behandling med deksametason.

Koronaviruset severe acute respiratory syndrome coronavirus 2 (SARS-CoV-2) har forårsaket en global pandemi med over 255 millioner bekreftede smittetilfeller og over 5 millioner dødsfall (1). Per 17.11.2021 var det totalt over 232 ooo bekreftede smittetilfeller og 995 
dødsfall forårsaket av covid-19 i Norge (2). Smitteutbredelsen i Norge har tatt form av bølger. Etter den første bølgen fra mars til juni 2020 fulgte tre måneder med lave smittetall. Andre bølge startet i september 2020, med synkende smittetall fra januar 2021. Fra slutten av februar 2021 økte antall nye tilfeller på nytt, fram til andre halvdel av mars $2021(\underline{2})$.

Folkehelseinstituttet har siden starten av pandemien publisert ukentlige rapporter om sykehusinnleggelser, intensivbehandling og dødsfall. Fram til 17.11.2021 ble over 5900 personer innlagt på sykehus i Norge som følge av covid-19. De alvorligste sykdomsforløpene var preget av respirasjonssvikt med utvikling av akutt lungesviktsyndrom, og over $1100(19 \%)$ av pasientene var innlagt på intensivavdeling (2). En tidlig beskrivelse av symptomer og sykdomsforløp hos de 42 første pasientene innlagt med covid-19 på Bærum sykehus ble publisert i Tidsskriftet allerede 10.4.2020 (3). Siden er det publisert få fullstendige beskrivelser av symptomer, behandling og sykdomsforløp fra kohorter av covid-19-pasienter innlagt ved norske sykehus, og så langt vi kjenner til, kun fra pandemiens første bølge (4-7.). Norsk pandemiregister har rapportert utvalgte pasientkarakteristika og dødelighet for tre bølger av sykehusinnlagte covid-19-pasienter i Norge ( $\underline{8})$.

I denne artikkelen presenteres pasientkarakteristika, behandling, sykdomsforløp og dødelighet for pasienter innlagt på Bærum sykehus på grunn av covid-19 i løpet av tre smittebølger over en periode på 16 måneder fra det første utbruddets start.

\section{Materiale og metode}

Samme uke som første pasient ble innlagt med covid-19 på Bærum sykehus, etablerte vi en prospektiv observasjonsstudie med mål om fortløpende å innhente og systematisere kunnskap om pasientkarakteristika, symptomer og sykdomsforløp. Bærum sykehus er et av de største lokalsykehusene i Norge, med et nedslagsfelt som omfatter cirka 190 ooo innbyggere i kommunene Asker og Bærum. Medisinsk avdeling har i en normal situasjon 92 sengeplasser, og intensivseksjonens kapasitet er vanligvis 4 respiratorsenger og 4 medisinske overvåkningssenger. Studiens metode er beskrevet i to tidligere publikasjoner om karakteristika og forløp hos de 42 og 73 første pasientene innlagt på sykehuset på grunn av covid-19 (3,4).

Første pasient på Bærum sykehus med påvist SARS-CoV-2 ble innlagt 9.3.2020, og alle pasienter som ble innlagt til og med 28.6.2021, ble inkludert i studien.

Vi definerte utbruddets første bølge som perioden 9.3--23.6.2020, og andre bølge som perioden 21.9.2020-28.2.2021. I perioden mellom 23.6.2020 og 21.9.2020 ble ingen pasienter innlagt på sykehuset med covid-19 som årsak. Tredje bølge ble definert som perioden 1.3.2021-28.6.2021. Det var ikke opphold i nye innleggelser mellom andre og tredje bølge, men 1.3.2021 ble valgt som startdato for tredje bølge fordi innleggelsesraten økte markant fra denne datoen. Etter 28.6.2021 fulgte flere uker uten nye innleggelser. Pasienter med påvist SARS-CoV-2 som var innlagt av andre årsaker enn covid-19-sykdom, ble ekskludert fra studien.

Basert på journalgjennomgang beregnet vi Charlsons komorbiditetsindeks (Charlson Comorbidity Index, CCI), hvor alder og kroniske sykdommer som hjerte- og lungesykdom, diabetes mellitus, demens og kreftsykdom gir poeng (9.).

Vi brukte den norske oversettelsen av Clinical Frailty Scale (CFS) til å beskrive skrøpelighet, basert på journalopplysninger om funksjonsnivå og hjelpebehov to uker forut for sykdomsdebut (10, $\underline{11})$. CFS-skår $\geq_{5}$ indikerer skrøpelighet, og høy skår er en uavhengig prediktor for død hos pasienter innlagt på sykehus med covid-19 (프).

Symptomer og symptomvarighet ble registrert basert på opplysninger fra innkomstjournal. Vi beregnet NEWS2-skår (National Early Warning Score 2) basert på første kliniske undersøkelse i akuttmottaket. I NEWS2-systemet skåres respirasjonsfrekvens, 
perifer oksygenmetning, systolisk blodtrykk, pulsfrekvens, bevissthetsnivå/forvirring og temperatur med 1-3 poeng og oksygenbehandling med 2 poeng (13). NEWS2-skår $\geq 5$ indikerer alvorlig akutt sykdom, og høy skår ved innkomst predikerer alvorlig sykdomsforløp og død hos pasienter innlagt på sykehus med covid-19 (14). Charlsons komoribitetsindeks, CFS-skår og NEWS2-skår ble beregnet for alle pasientene i studien.

Hypoksemi med behov for oksygenbehandling ble definert som respirasjonssvikt. Vi har ikke oversikt over hva som lå til grunn for oksygenbehandling i hvert enkelt tilfelle, men en vanlig tilnærming er å starte med oksygen ved $\mathrm{SpO}_{2} \leq 93 \% \mathrm{i}$ romluft.

Røyking, vekt og høyde ble registrert når denne informasjonen var tilgjengelig i pasientjournal. Kroppsmasseindeks (BMI) ble beregnet basert på vekt og høyde dokumentert i journal. Laboratoriesvar ble hentet fra laboratoriearket i pasientjournal.

Dødelighet ble definert som død i løpet av sykehusoppholdet, og ble beregnet ved å dividere antall døde i en bølge med alle pasienter innlagt på grunn av covid-19 i samme bølge.

ETIKK

Studien ble godkjent av personvernombudet i Vestre Viken helseforetak (20/02772-1). Kravet om informert samtykke ble frafalt, da dette var en kvalitetsstudie som kun benyttet rutinemessig innsamlede kliniske data. Informasjon om studien og reservasjonsrett ble distribuert per post til overlevende pasienter, men ingen benyttet muligheten til å trekke seg.

\section{DATABEHANDLING}

Data ble registrert i EpiData versjon 4.4.3.1 (EpiData Association, Odense, Danmark). Kontinuerlige variabler er angitt som gjennomsnitt. Da noen av gjennomsnittsverdiene ble betydelig påvirket av ekstremverdier, har vi valgt å også rapportere median med spredning (min.-maks.). Kategoriske variabler er rapportert som antall og andel (\%). Da studiens hensikt ikke var å undersøke effekter av pasientkarakteristika eller behandling, og da eventuelle forskjeller mellom de tre bølgene sannsynligvis ble påvirket av variabler som ikke inngikk i vår studie, har vi valgt å ikke rapportere resultater av sammenlignende statistiske analyser. Databearbeiding ble utført i SPSS versjon 25.o (IBM, Armonk, NY, USA).

\section{Resultater}

Fra starten av det lokale covid-19-utbruddet i mars 2020 og fram til 28.6.2021 ble 319 pasienter innlagt på Bærum sykehus med påvist SARS-CoV-2. Etter eksklusjon av 17 pasienter innlagt av andre årsaker enn covid-19 og 2 pasienter overflyttet fra andre sykehus underveis i sykdomsforløpet ble zoo pasienter inkludert.

Figur 1 viser antall nye innlagte pasienter, antall innlagte på intensivavdeling og antall innlagte på vanlig sengepost på grunn av covid-19 for hver dag. Det høyeste antallet innlagte på samme dato var 29, og det høyeste antallet intensivpasienter var 9. 
Antall pasienter

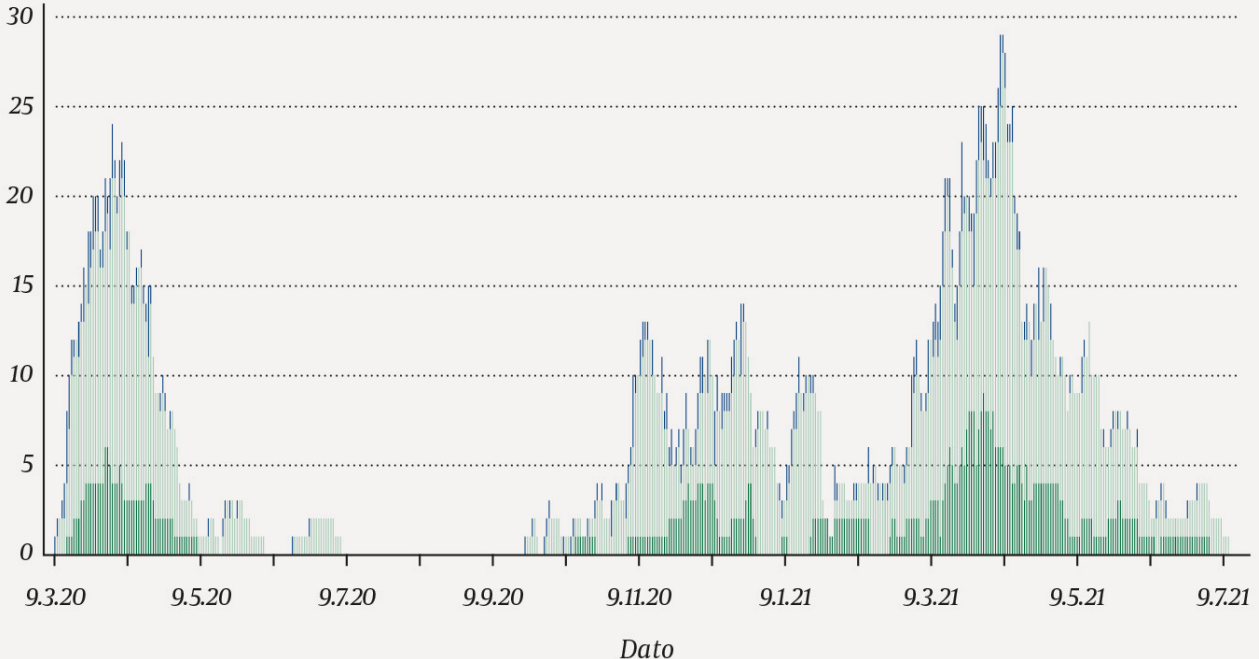

Figur 1 Pasienter innlagt på Bærum sykehus på grunn av covid-19 i perioden 9.3.202028.6.2021 $(n=300)$. Søylene viser totalt antall pasienter som var innlagt, samt antall pasienter på intensivavdeling, antall pasienter på vanlig sengepost og antall nye innlagte pasienter for hver dag i perioden.

Figur 2 gir oversikt over pasienter inkludert i studien og dødelighet per bølge. I alt 30 pasienter (10 \%) døde i løpet av sykehusoppholdet, hvorav 14 (18\%) under første bølge, 11 (11\%) under andre og 5 (4\%) under tredje. Gjennomsnittsalderen blant de som døde, var henholdsvis 79,5, 78,7 og 67,8 år.

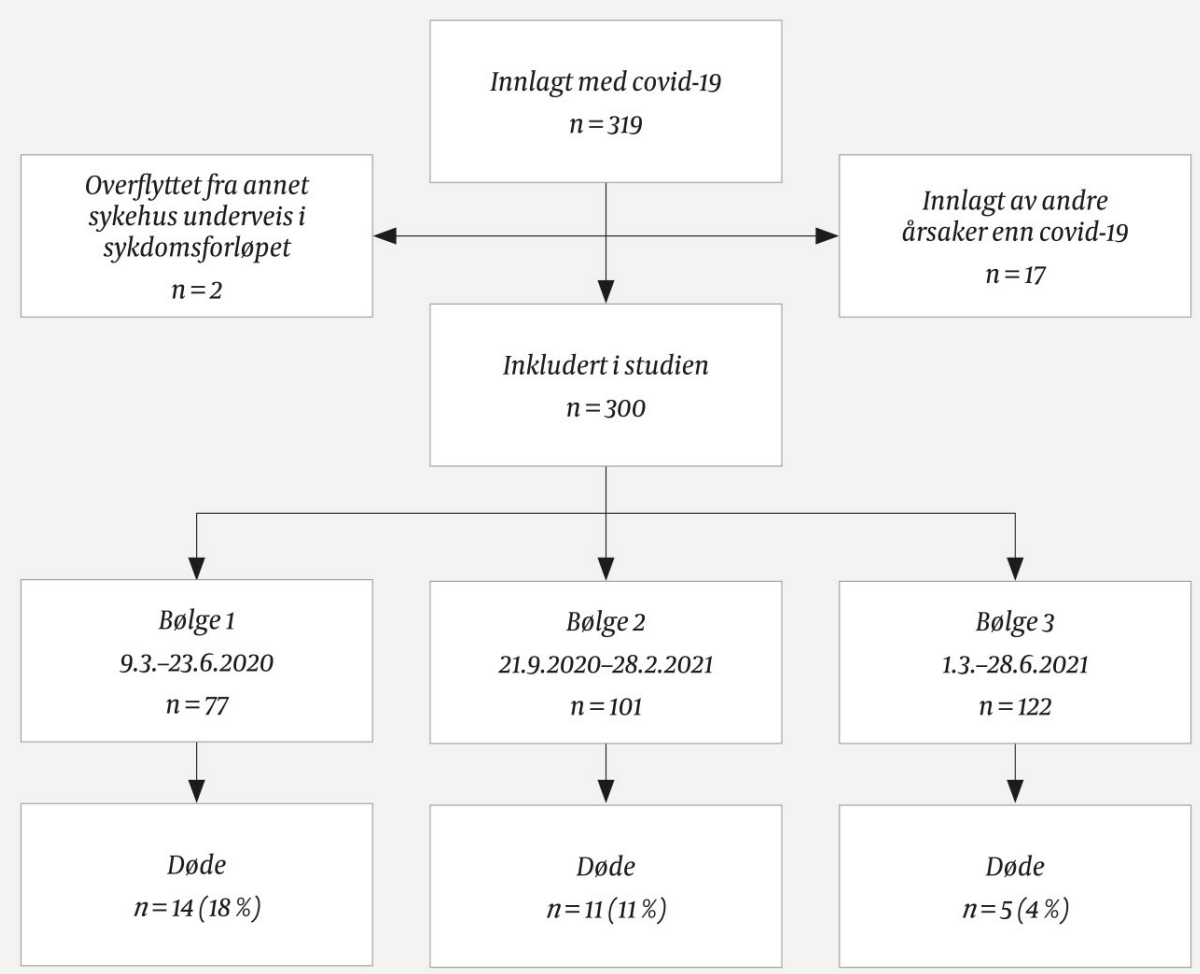

Figur 2 Fordelingen av studiepopulasjonen $(n=300)$ på tre smittebølger og dødeligheten i hver av de tre bølgene. 
Gjennomsnittsalderen blant alle innlagte var 59,7 år, og 189 (63\%) var menn. Tabell 1 viser utvalgte pasientkarakteristika. Gjennomsnittsalderen for innlagte pasienter i de tre bølgene var henholdsvis 67,6, 61,5 og 53,3 år, og alderssammensetningen varierte mellom bølgene (figur 3).

\section{Tabell 1}

Utvalgte karakteristika hos pasienter innlagt på Bærum sykehus på grunn av covid-19 $\mathrm{i}$ løpet av første (9.3.-23.6.2020), andre (21.9.2020-28.2.2021) og tredje (1.3.-28.6.2021) smittebølge, $n=300$. Gjennomsnitt (median; min.-maks.) dersom annet ikke er angitt. CFS = Clinical Frailty Scale.

\begin{tabular}{|c|c|c|c|}
\hline Karakteristikum & $\begin{array}{l}\text { Første bølge } \\
(n=77)\end{array}$ & $\begin{array}{l}\text { Andre bølge } \\
(n=101)\end{array}$ & $\begin{array}{l}\text { Tredje bølge } \\
(n=122)\end{array}$ \\
\hline Alder (år) & $67,6(71 ; 30-95)$ & $61,5(60 ; 21-97)$ & $53,3(51 ; 23-82)$ \\
\hline Menn, antall (\%) & $46(60)$ & $66(65)$ & $77(63)$ \\
\hline Kroppsmasseindeks $\left(\mathrm{kg} / \mathrm{m}^{2}\right)^{1}$ & $\begin{array}{r}25,8 \\
(25,6 ; 16,8-37,0)\end{array}$ & $\begin{array}{r}27,2 \\
(27,0 ; 16,3-42,5)\end{array}$ & $\begin{array}{r}28,5 \\
(27,3 ; 18,6-49,7)\end{array}$ \\
\hline $\begin{array}{l}\text { Røyker, nå eller tidligere, antall } \\
(\%)^{2}\end{array}$ & $27(38)$ & 27 (32) & 39 (34) \\
\hline CFS-skår ${ }^{3}$ & $3,0(2 ; 1-7)$ & $2,6(2 ; 1-7)$ & $2,5(2 ; 1-7)$ \\
\hline Charlsons komorbiditetsindeks & $3,4(3 ; 0-14)$ & $2,6(2 ; 0-10)$ & $1,5(1 ; 0-9)$ \\
\hline Skrøpelig (CFS-skår $\geq 5$ ), antall (\%) & $20(26)$ & $10(10)$ & $7(6)$ \\
\hline \multicolumn{4}{|l|}{ Komorbide tilstander, antall (\%) } \\
\hline Hypertensjon & $21(27)$ & $23(23)$ & $28(23)$ \\
\hline Diabetes mellitus & $11(14)$ & $18(18)$ & $23(19)$ \\
\hline Andre & $34(44)$ & $45(45)$ & 40 (33) \\
\hline
\end{tabular}

${ }^{1}$ Informasjon om kroppsmasseindeks manglet hos 12 pasienter i første bølge, 10 i andre og 5 i tredje.

${ }^{2}$ Informasjon om røyking manglet hos 6 pasienter i første bølge, 16 i andre og 8 i tredje.

${ }^{3}$ Basert på journalopplysninger om funksjonsnivå og hjelpebehov to uker forut for sykdomsdebut. 


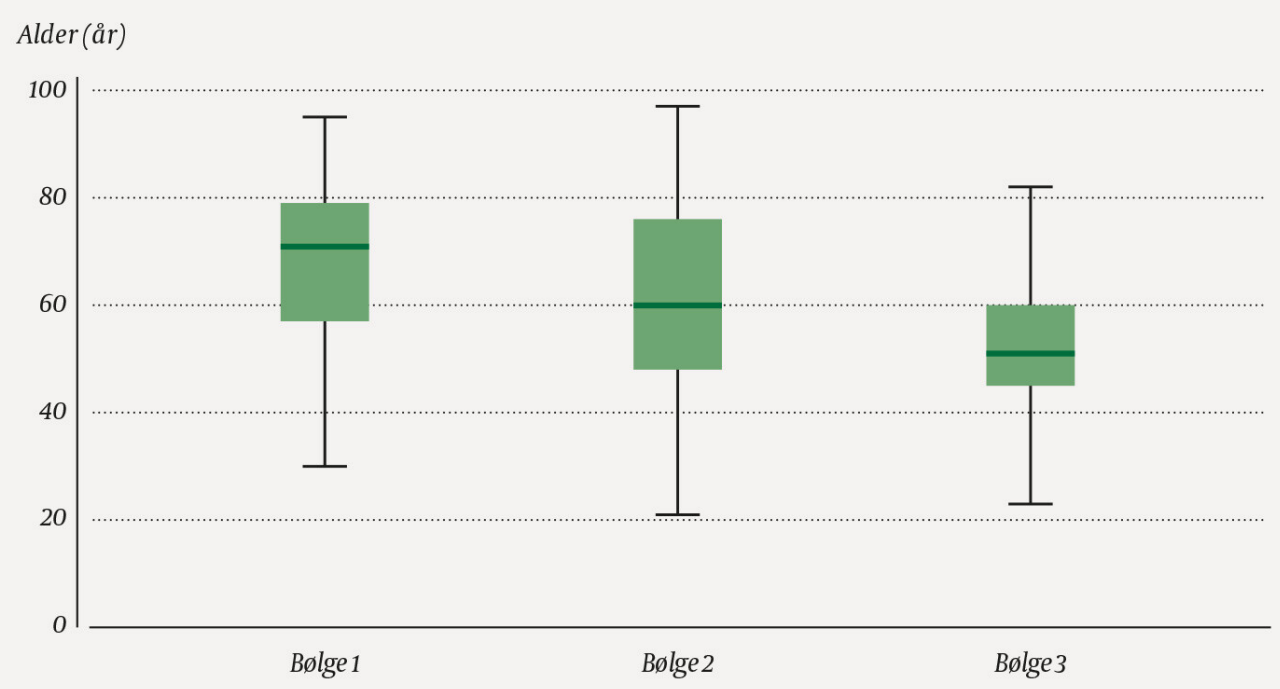

Figur 3 Aldersfordeling blant pasienter innlagt på Bærum sykehus på grunn av covid-19 per aldersgruppe i første $(n=77)$, andre $(n=101)$ og tredje $(n=122)$ smitteb $ø \operatorname{lge}, n=300$. Figuren viser median, andre og tredje kvartil og spredning (min.-maks.) for alder i hver bølge. Tabell 2 viser symptomer og utvalgte funn for de tre bølgene. Det var ingen tydelige forskjeller i symptomer, inflammasjonsmarkører eller NEWS2-skår ved innkomst. Gjennomsnittlig antall døgn på sykehus var 10,3 (median 10; min.-maks. 2-39) i første bølge, 9,3 (7; 1-64) i andre og 11,7 (9;1-80) i tredje. Henholdsvis 59 (79\%), 99 (98\%) og 113 (93\%) fikk tromboseprofylaktisk behandling. Antall pasienter med påvist venøs tromboembolisme var 5(7\%), 5 (5\%) og 4 (3\%).

\section{Tabell 2}

Symptomer rapportert ved innkomst, NEWS2-skår i akuttmottaket og inflammasjonsmarkører hos pasienter innlagt på Bærum sykehus på grunn av covid-19 i løpet av første (9.3--23.6.2020), andre (21.9.2020-28.2.2021) og tredje (1.3--28.6.2021) smitteb $\varnothing \operatorname{lge}, n=300$. Gjennomsnitt (median; min.-maks.) dersom annet ikke er angitt. NEWS 2 = National Early Warning Score 2.

\begin{tabular}{|c|c|c|c|}
\hline & $\begin{array}{l}\text { Første bølge }(n= \\
77)\end{array}$ & $\begin{array}{l}\text { Andre bølge }(n= \\
101)\end{array}$ & $\begin{array}{l}\text { Tredje bølge }(n= \\
\text { 122) }\end{array}$ \\
\hline $\begin{array}{l}\text { Dager med symptomer før } \\
\text { innleggelse }\end{array}$ & $8,5(7 ; 0-22)$ & $7,3(7 ; 1-21)$ & $7,3(8 ; 0-20)$ \\
\hline \multicolumn{4}{|l|}{ Symptomer, antall (\%) } \\
\hline Hoste & $47(61)$ & $56(55)$ & $67(55)$ \\
\hline Dyspné & $49(64)$ & $58(57)$ & $83(68)$ \\
\hline Feber & $55(71)$ & $71(70)$ & $97(80)$ \\
\hline Redusert allmenntilstand & $61(79)$ & $72(71)$ & $94(77)$ \\
\hline Andre & $52(68)$ & $85(84)$ & $91(75)$ \\
\hline $\begin{array}{l}\text { NEWS2-skår } \geq 5 \text { ved innkomst, antall } \\
\text { (\%) }\end{array}$ & $33(43)$ & $46(46)$ & $53(43)$ \\
\hline NEWS2-skår ved innkomst & $4,3(4 ; 0-13)$ & $4,6(4 ; 0-13)$ & $4,2(4 ; 0-12)$ \\
\hline CRP (mg/L) ved innkomst & $61(50 ; 3-257)$ & $71(51 ; 3-307)$ & $74(47 ; 4-293)$ \\
\hline
\end{tabular}




\begin{tabular}{|c|c|c|c|}
\hline & $\begin{array}{l}\text { Første bølge }(n= \\
77)\end{array}$ & $\begin{array}{l}\text { Andre bølge }(n= \\
\text { 101) }\end{array}$ & $\begin{array}{l}\text { Tredje bølge }(n= \\
\text { 122) }\end{array}$ \\
\hline $\begin{array}{l}\text { CRP (mg/L), høyeste verdi under } \\
\text { sykehusoppholdet }^{1}\end{array}$ & $127(119 ; 3-432)$ & $102(77 ; 3-441)$ & $109(98 ; 4-407)$ \\
\hline Ferritin $(\mu \mathrm{g} / \mathrm{L})$ ved innkomst ${ }^{2}$ & $\begin{array}{r}685(472 ; 66- \\
3283)\end{array}$ & $\begin{array}{r}678(440 ; 29- \\
6195)\end{array}$ & $\begin{array}{r}688(458 ; 13- \\
6152)\end{array}$ \\
\hline $\begin{array}{l}\text { Ferritin }(\mu \mathrm{g} / \mathrm{L}) \text {, høyeste verdi under } \\
\text { sykehusoppholdet }^{2}\end{array}$ & $\begin{array}{r}1213(833 ; 28- \\
5603)\end{array}$ & $\begin{array}{r}1144(716 ; 47- \\
8216)\end{array}$ & $\begin{array}{r}1338(750 ; 16- \\
33511)\end{array}$ \\
\hline Lymfocytter $\left(\times 10^{9} / \mathrm{L}\right)$ ved innkomst ${ }^{3}$ & $1,1(1,0 ; 0,2-4,9)$ & $1,1(1,0 ; 0,3-3,2)$ & $1,0(0,9 ; 0,2-2,6)$ \\
\hline $\begin{array}{l}\text { Lymfocytter }\left(\times 10^{9} / \mathrm{L}\right) \text {, laveste verdi } \\
\text { under sykehusoppholdet }{ }^{3}\end{array}$ & $0,9(0,7 ; 0,1-2,9)$ & $0,9(0,9 ; 0,1-2,0)$ & $0,8(0,8 ; 0,1-2,6)$ \\
\hline
\end{tabular}

${ }^{1}$ Informasjon om CRP underveis i oppholdet manglet hos 1 pasient i første bølge, 2 i andre og 1 i tredje.

${ }^{2}$ Informasjon om ferritin ved innleggelse manglet hos 32 pasienter i første bølge, 9 i andre $\operatorname{og}_{5} \mathrm{i}$ tredje. Informasjon om ferritin underveis i oppholdet manglet hos 10 pasienter $\mathrm{i}$ første bølge, 2 i andre og 1 i tredje.

3Informasjon om lymfocytter ved innleggelse manglet hos 1 pasient $\mathrm{i}$ andre bølge og $1 \mathrm{i}$ tredje. Informasjon om lymfocytter underveis i oppholdet manglet hos 2 pasienter i første bølge og 1 i tredje.

Totalt 204 pasienter (68\%) ble behandlet for respirasjonssvikt, og andelen pasienter med respirasjonssvikt var stabil gjennom de tre bølgene: Henholdsvis 52 av 77 (68\%), 69 av 101 (68\%) og 83 av 122 (68\%) ble behandlet for respirasjonssvikt i første, andre og tredje bølge. Av disse ble 143 (70\%) behandlet med nesekateter og 30 (15\%) med nasal høyluftstrømskanyle (Optiflow) eller ikke-invasiv ventilasjonsstøtte som høyeste nivå av behandling for respirasjonssvikt. Totalt 31 pasienter (15\%) ble behandlet med invasiv ventilasjonsstøtte, og gjennomsnittlig antall dager fra innleggelse til intubasjon for disse var 5,9 (median 5; min.-maks. 1-28). 21 av de 31 fikk behandling med ikke-invasiv ventilasjonsstøtte eller nasal høyluftstrømskanyle i gjennomsnittlig 5,3 dager (3; 1-23) før intubasjon. I andre og tredje bølge fikk henholdsvis 53 av 69 (77\%) og 72 av 83 (87\%) pasienter med respirasjonssvikt behandling med deksametason i gjennomsnittlig 12,o (10; 1-64) dager. 43 av disse (28\%) fikk deksametason i mer enn 10 dager. Tabell 3 viser behandling av respirasjonssvikt i de tre bølgene.

\section{Tabell 3}

Behandling og dødelighet blant pasienter med respirasjonssvikt innlagt på Bærum sykehus på grunn av covid-19 i løpet av første (9.3.-23.6.2020), andre (21.9.2020-28.2.2021) og tredje (1.3.-28.6.2021) smittebølge, $n=204$. Gjennomsnitt (median; min.-maks.) dersom annet ikke er angitt.

\begin{tabular}{|lrrr|}
\hline & $\begin{array}{l}\text { Første bølge } \\
(n=52)\end{array}$ & $\begin{array}{l}\text { Andre bølge } \\
(n=69)\end{array}$ & $\begin{array}{l}\text { Tredje bølge } \\
(n=83)\end{array}$ \\
\hline Nesekateter, antall (\%) & $39(75)$ & $53(77)$ & $51(61)$ \\
\hline $\begin{array}{l}\text { Ikke-invasiv ventilasjonsstøtte, antall } \\
(\%)^{1,2}\end{array}$ & $4(8)$ & $9(13)$ & $17(20)$ \\
\hline Invasiv ventilasjonsstøtte, antall (\%) & $9(17)$ & $7(10)$ & $15(18)$ \\
\hline
\end{tabular}




\begin{tabular}{|lccc|}
\hline & $\begin{array}{l}\text { Første bølge } \\
(n=52)\end{array}$ & $\begin{array}{l}\text { Andre bølge } \\
(n=69)\end{array}$ & $\begin{array}{l}\text { Tredje bølge } \\
(n=83)\end{array}$ \\
\hline $\begin{array}{l}\text { Dager innlagt før invasiv } \\
\text { ventilasjonsstøtte }\end{array}$ & $3,4(2 ; 1-8)$ & $10,7(8 ; 2-28)$ & $5,1(5 ; 1-11)$ \\
\hline $\begin{array}{l}\text { Dager behandlet med invasiv } \\
\text { ventilasjonsstøtte }\end{array}$ & $16,0(18 ; 2-25)$ & $14,4(8 ; 4-36)$ & $11,9(8 ; 4-49)$ \\
\hline $\begin{array}{l}\text { Død under sykehusoppholdet etter } \\
\text { behandling med invasiv } \\
\text { ventilasjonsstøtte, antall (\%) }\end{array}$ & $5(56)$ & $4(57)$ & $4(27)$ \\
\hline
\end{tabular}

${ }^{1}$ Antall pasienter som fikk slik behandling som høyeste nivå av behandling mot respirasjonssvikt.

${ }^{2}$ Inkluderer pasienter som fikk behandling med nasal høyluftstrømskanyle.

${ }^{3}$ Andel av alle behandlet med invasiv ventilasjonsstøtte.

\section{Diskusjon}

Antall innlagte pasienter med covid-19 på Bærum sykehus fulgte samme utvikling som i samfunnet ellers, med tre bølger. I alle tre bølgene, men særlig i første bølge, hadde Bærum sykehus et høyt antall innlagte sett i forhold til innbyggertall og antall sykehusinnlagte i hele landet (므). Ifølge Norsk pandemiregisters rapport var dødeligheten blant pasienter innlagt på norske sykehus henholdsvis 7,7\%, 7,2 \% og 4,8 \% i de tre bølgene, mens gjennomsnittsalderen var 59,8, 58,8 og 53,7 år ( $\underline{8}$ ). Vi tror den betydelig høyere dødeligheten på Bærum sykehus under første bølge i stor grad kan forklares av den høyere gjennomsnittsalderen. De fleste pasientene som døde ved vårt sykehus under første bølge, var sårbare eller skrøpelige, og flertallet ble vurdert som for skrøpelige til å tåle respiratorbehandling (4.). Lokale smitteutbrudd på sykehjem var blant årsakene til at mange eldre med skrøpelighet ble lagt inn på Bærum sykehus under første bølge.

Resultatene fra Bærum sykehus fra andre og tredje bølge er trolig mer representative for pasientkohorter på norske sykehus, da både gjennomsnittsalder og dødelighet var mer sammenlignbare med landsgjennomsnittet og publiserte data fra sykehuskohorter i Norge fra første bølge $(5, \underline{6}, \underline{8})$. Blant 70 innlagte covid-19-pasienter inkludert i en studie ved Sykehuset Østfold var dødeligheten $10 \%$ ( 7 av 70) (5), og ved Oslo universitetssykehus døde 13 av 169 (7\%) pasienter som var inkludert i en studie under utbruddets første bølge (므).

Forekomsten av risikofaktorer som hypertensjon og diabetes mellitus var relativt lik i de tre bølgene, noe som samsvarer med funn fra pandemiregisteret (요). Kroppsmasseindeks ser ut til å ha vært høyere i andre og tredje bølge. Også dette er i samsvar med data fra pandemiregisteret, hvor gjennomsnittlig kroppsmasseindeks var henholdsvis 27,7 og $29,3 \mathrm{~kg} / \mathrm{m}^{2}$ i første og tredje bølge (ㅁ). Overvekt har i flere studier vist seg å disponere for alvorlig forløp av covid-19, trolig grunnet lavgradig respirasjonssvikt forårsaket av stort bukomfang (15). I tillegg er det kjent fra andre pasientgrupper at overvekt er forbundet

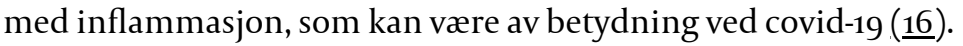

Behandlingen av alvorlig respirasjonssvikt har endret seg siden starten av pandemien. Det er fortsatt ikke konsensus om hvilken behandlingsmetode som er best, og praksis varierer. Behandling med deksametason i inntil ti dager ble hyppig brukt ved respirasjonssvikt under andre og tredje bølge, basert på foreløpige resultater fra RECOVERY-studien, som ble publisert i juli 2021 (17). . Da mer langvarig steroidbehandling er forbundet med økt risiko for bivirkninger ( $\underline{18})$, ble behandling utover ti dager vurdert individuelt hos pasienter med alvorlig respirasjonssvikt. Mageleie ble etter hvert brukt systematisk på 
intensivavdelingen, og i mindre grad også hos pasienter med mindre alvorlig respirasjonssvikt. I begynnelsen av pandemien ble ikke-invasiv ventilasjonsst $ø$ tte og nasal høyluftstrømskanyle lite brukt på grunn av smittevernhensyn, mens slik behandling ble noe mer brukt under den andre og tredje bølgen. Hvorvidt tidspunkt for intubasjon påvirker dødeligheten hos pasienter med covid-19 og alvorlig respirasjonssvikt, er omdiskutert $(\underline{19}, \underline{20})$. Vi vurderte tidspunkt for intubasjon for hver enkelt pasient ut fra grad av respirasjonssvikt, respons på ikke-invasiv ventilasjonsstøtte, hvor påvirket pasientens respirasjon var, hvor lenge pasienten hadde vært syk, og andre faktorer som for eksempel sirkulasjonspåvirkning og laktatnivå.

Både økt kunnskap og erfaring kan ha bidratt til forbedret behandling av respirasjonssvikt og forebygging av alvorlige komplikasjoner underveis i pandemien. Venøs tromboembolisme ble tidlig identifisert som en hyppig komplikasjon ved covid-19 (4, $\underline{21})$, og åtte av ti fikk tromboseprofylaktisk behandling i første bølge. Under andre og tredje bølge var andelen over $90 \%$.

Selv om endringer i behandlingen kan ha bidratt til lavere dødelighet, kan også andre forhold som utbredelse av ulike virusvarianter i samfunnet og vaksinasjonsstatus ha hatt betydning. Virusvarianten B.1.1.7 (britisk variant) ble dominerende i løpet av andre bølge (ㅁ) og ble rapportert å være forbundet med høyere dødelighet enn det opprinnelige viruset (22). Varianten B.1.617.2 (delta) ble påvist i Norge i midten av april 2021 og ble raskt dominerende i Viken og Oslo (23). Antallet sykehusinnlagte og døde med påvist deltavariant i Norge var imidlertid lavt fram til 15.8.2021 (24). $)$. Vi hadde dessverre ikke tilgang til fullstendige data om virusvarianter i studien, men nye varianter ser ikke ut til å ha medført økt dødelighet blant sykehusinnlagte i vår studie. Vaksinasjon mot covid-19 i Norge startet 27.12.2020, og eldre og personer med risikofaktorer ble vaksinert først. Hvordan den gradvis $ø$ kende andelen vaksinerte i befolkningen under andre og tredje bølge påvirket dødeligheten blant sykehusinnlagte, er vanskelig å anslå. Da eldre med skrøpelighet har høyest risiko for alvorlig sykdom og død ved covid-19, er det imidlertid grunn til å anta at den lavere dødeligheten under tredje bølge i stor grad skyldes at denne gruppen var vaksinert, og at vaksinen var effektiv i å forhindre alvorlig sykdom og død.

Særlig under første bølge bidro den uavklarte smittesituasjonen i samfunnet og en rask $\emptyset$ kning i antall innlagte med covid-19 til betydelig påvirkning av både sykehusdriften og de ansatte. I april 2020, 25 dager etter at første pasient med covid-19 ble innlagt på sykehuset, var det høyeste antallet samtidig innlagte 24 . Fram til mai 2020 var det opptil ett døgns svartid på covid-19-tester, og derfor mange pasienter med uavklart smittestatus. I perioder med mange innlagte ble kapasiteten ved både intensivavdelingen og infeksjonsavdelingen $\varnothing \mathrm{kt}$, blant annet gjennom at operasjonsdrift ble redusert, postoperativ avdeling ble omgjort til intensivavdeling, og ny sengepost ble åpnet.

\section{KONKLUSJONER}

To av tre pasienter innlagt på Bærum sykehus på grunn av covid-19 ble behandlet for respirasjonssvikt. Endringer i både pasientkarakteristika og behandling, f.eks. bruk av deksametason og ikke-invasiv ventilasjonsst $ø$ tte, kan ha bidratt til at dødeligheten tilsynelatende var lavere under andre og tredje smittebølge. Faktorer som ikke er registrert i studien, slik som informasjon om vaksinasjonsstatus, kan også ha påvirket dødeligheten.

Artikkelen er fagfellevurdert.

\section{LITTERATUR}

1. WHO. Coronavirus disease (COVID-19) pandemic.

https://www.who.int/emergencies/diseases/novel-coronavirus-2019 Lest 22.11.2021.

2. Folkehelseinstituttet. Statistikk om koronavirus og covid-19. https://www.fhi.no/sv/smittsommesykdommer/corona/dags--og-ukerapporter/dags--og-ukerapporter-om-koronavirus/ Lest 17.11.2021. 
3. Ihle-Hansen H, Berge T, Tveita A et al. Covid-19: Symptomer, forløp og bruk av kliniske skåringsverktøy hos de 42 første pasientene innlagt på et norsk lokalsykehus. Tidsskr Nor Legeforen 2020; 140. doi: 10.4045/tidsskr.20.0301. [PubMed][CrossRef]

4. Ihle-Hansen H, Berge T, Ernø PE et al. Komplikasjoner og dødelighet blant pasienter innlagt med covid-19. Tidsskr Nor Legeforen 2020; 140. doi: 10.4045/tidsskr.20.0432. [PubMed][CrossRef]

5. Øverstad S, Tjønnfjord E, Olsen MK et al. 7o pasienter med covid-19 innlagt ved Sykehuset Østfold. Tidsskr Nor Legeforen 2020; 140. doi: 10.4045/tidsskr.20.0612. [PubMed][CrossRef]

6. Holten AR, Nore KG, Tveiten CEVWK et al. Predicting severe COVID-19 in the Emergency Department. Resusc Plus 2020; 4. doi:10.1016/j.resplu.2020.100042. [PubMed][CrossRef]

7. Søvik S, Bådstøløkken PM, Sørensen V et al. A single-centre, prospective cohort study of COVID-19 patients admitted to ICU for mechanical ventilatory support. Acta Anaesthesiol Scand 2021; 65:351-9. [PubMed][CrossRef]

8. Helse Bergen. Norsk pandemiregister. https://helse-bergen.no/norsk-

pandemiregister\#manadlege-rapportar-fra-pandemiregisteret Lest 17.11.2021.

9. Charlson ME, Pompei P, Ales KL et al. A new method of classifying prognostic comorbidity in longitudinal studies: development and validation. J Chronic Dis 1987; 40:373-83. [PubMed][CrossRef]

10. Rockwood K, Song X, MacKnight C et al. A global clinical measure of fitness and frailty in elderly people. CMAJ 2005; 173: 489-95. [PubMed][CrossRef]

11. Rostoft S, Engstad TT, Sjøbø B et al. Clinical Frailty Scale - Norwegian.

https://www.legeforeningen.no/contentassets/21ef25cf569d44749573de21a8d6bo43/cfs_norsk_horison tal_2021.pdf Lest 17.11.2021.

12. COPE Study Collaborators. The effect of frailty on survival in patients with COVID-19(COPE): a multicentre, European, observational cohort study. Lancet Public Health 2020; 5: e444-51. [PubMed] [CrossRef]

13. National Early Warning Score (NEWS) 2: Standardising the assessment of acute-illness severity in the NHS. Updated report of a working party. London: Royal College of Physicians, 2017.

https://www.rcplondon.ac.uk/projects/outputs/national-early-warning-score-news-2 Lest 17.11.2021.

14. Myrstad M, Ihle-Hansen H, Tveita AA et al. National Early Warning Score 2 (NEWS2) on admission predicts severe disease and in-hospital mortality from Covid-19 - a prospective cohort study. Scand J Trauma Resusc Emerg Med 2020; 28: 66. [PubMed][CrossRef]

15. Sanchis-Gomar F, Lavie CJ, Mehra MR et al. Obesity and outcomes in COVID-19: When an epidemic and pandemic collide. Mayo Clin Proc 2020; 95:1445-53. [PubMed][CrossRef]

16. Kawai T, Autieri MV, Scalia R. Adipose tissue inflammation and metabolic dysfunction in obesity. Am J Physiol Cell Physiol 2021; 320: C375-C91. [PubMed][CrossRef]

17. RECOVERY Collaborative Group. Dexamethasone in hospitalized patients with Covid-19. N Engl J Med 2021;384: 693-704. [PubMed][CrossRef]

18. Mishra GP, Mulani J. Corticosteroids for COVID-19: the search for an optimum duration of therapy. Lancet Respir Med 2021; 9: e8. [PubMed][CrossRef]

19. Vera M, Kattan E, Born P et al. Intubation timing as determinant of outcome in patients with acute respiratory distress syndrome by SARS-CoV-2 infection. J Crit Care 2021; 65:164-9. [PubMed][CrossRef]

20. Papoutsi E, Giannakoulis VG, Xourgia E et al. Effect of timing of intubation on clinical outcomes of critically ill patients with COVID-19: a systematic review and meta-analysis of non-randomized cohort studies. Crit Care 2021; 25: 121. [PubMed][CrossRef]

21. Tveita A, Hestenes S, Sporastøyl ER et al. Lungeembolisme ved covid-19. Tidsskr Nor Legeforen 2020;140. doi: 10.4045/tidsskr.20.0366. [PubMed][CrossRef]

22. CMMID COVID-19 Working Group. Increased mortality in community-tested cases of SARS-CoV-2 lineage B.1.1.7. Nature 2021; 593: 270-4. [PubMed][CrossRef]

23. Covid-19-epidemien: Risiko ved covid-19-epidemien i Norge i lys av framveksten av Deltavarianten av SARS-CoV-2. Rapport. Oslo: Folkehelseinstituttet, 2021.

https://www.fhi.no/contentassets/c9e459cd7cc24991810aod28d7803bdo/2021-07-26-risiko-ved-covid-19epidemien-i-norge-i-lys-av-framveksten-av-delta-varianten-av-sars-cov-2-.pdf Lest 17.11.2021.

24. Seppälä E, Veneti L, Starrfelt J et al. Vaccine effectiveness against infection with the Delta (B.1.617.2) variant, Norway, April to August 2021. Euro Surveill 2021; 26: 2100793. [PubMed][CrossRef]

Publisert: 27. desember 2021. Tidsskr Nor Legeforen. DOI: 10.4045/tidsskr.21.0750

Mottatt 22.10.2021, første revisjon innsendt 26.11.2021, godkjent 3.12.2021. 
Publisert under åpen tilgang CC BY-ND. Lastet ned fra tidsskriftet.no 26. april 2023. 